\title{
Institutional Development and Good Governance Assessments in Croatia: An Extended Focus on Corruption
}

\author{
Zoran Aralica * \\ Jelena Budak*
}

\begin{abstract}
This paper examines good governance assessments in Croatia and in selected CEE countries. It aims to confirm that the quality of governance should be evaluated by considering phenomena- or country-specific institutional environment. Based on the analysis of good governance indicators slight improvements in all dimensions of good governance for all of the selected countries were observed in a period from 1996 to 2002. Using constructed aggregate Good Governance Index (GGI) and Human Development Index (HDI) tested the general assumption that good governance is connected to economic and social development. Spearman rank order correlation analysis confirmed that for all selected countries in 2000 there was a high positive correlation between their GGI rank and HDI rank. The correlation matrix for CEE countries in 2000 confirmed our hypothesis that government effectiveness; regulatory quality and rule of law positively correlate with control of corruption. The paper concludes that research on interdependencies among good governance and development indicators as well as on determinants and effects of good governance dimensions remains to be done for Croatia.
\end{abstract}

JEL Classification: $\mathrm{P} 37, \mathrm{H} 11$

Key words: institutional development, good governance, human development, correlation. corruption

\section{Introduction}

The transition process pointed out both governance and institutional quality issues. However, the relation between institutional development and governance quality seems to remain still unclear, therefore affecting measuring institutional and/or good governance assessments. Models set in numerous research efforts to provide us with qualitative institutional and governance analyses (Van de Mortel 2002, Jeffries 2001)

* Zoran Aralica and Jelena Budak are at the Institute of Economics, Zagreb, Croatia. 
attempt to explain interaction between institutional development and good governance. However, the definition of governance and institutions is still a matter of discussion and so are the governance and institutional development assessment indicators seldom put together as one country's development determinants ${ }^{1}$. The World Bank papers on indicators of governance and institutional quality measure performance (assessments of governance), and process (institutional inputs that produce governance outcomes) ${ }^{2}$. This work aims to confirm that good governance assessments should be evaluated taking into consideration the related phenomena or country-specific institutional framework. The thesis will be tested through the analysis of good governance indicators for selected countries in transition and more deeply through institutional analysis of corruption in Croatia.

This paper starts with the definition of institutions and dimensions of good governance. In the next chapter we will analyse good governance assessments of selected CEE countries and comment good upon governance indicators' values for Croatia for period 1996-2002. We will then investigate if overall good governance quality is associated with economic and social development. The Spearman rank order correlation analysis will be applied to test the positive correlation between selected countries' Good Governance Index and Human Development Index ranks. The connection among development indices and good government indicators for the selected CEE countries will be tested by constructed correlation matrix. More detailed analysis will follow by examining correlation of good governance indicators for Croatia.

Corruption as one dimension of good governance has been chosen for the case study of Croatia. We will investigate corruption at the national and local level accompanied with the explanations of the specific institutional environment. That analysis lead to the conclusion of the paper where we will confirm our thesis that good governance assessments are to be evaluated by considering phenomena- and country-specific institutional development.

\section{Institutions and Good Governance}

Institutions are considered man-made rules shared in a community and always enforced by some sort of sanctions. Certain types of institutions may have deleterious consequences for welfare, freedom and other human values and therefore lead to economic and social decline. The key function of institutions is to facilitate order and therefore to reduce costs of coordination. Internal institutions evolve from human experience such as ethical norms where sanctions are informal but nevertheless effective, while external institutions are imposed by agents authorised by the political process such as legislation (Kasper and Streit, 1998). North (1990) gives the similar 
definition of institutions, but goes a step further arguing their evolving attributes and the impact of institutional change on economic performance. For North, institutions are the rules of the game in a society,..., humanly devised constraints that shape human interaction with a major role to reduce uncertainty. Formal and informal constraints $^{3}$ may be created institutions or evolving institutions. Institutions are affecting the performance of an economy by their effect on the transaction and transformation costs. There is a distinction between institutions and organisations. Organisations have been developed as a consequence of an institutional framework. The emphasis of the institutional analysis therefore is on the interaction between institutions as the rule of the game and organisations as agents of institutional change (North, 1990).

Scheme 1: Dimensions of Good Governance and the Relating Indicators ${ }^{4}$

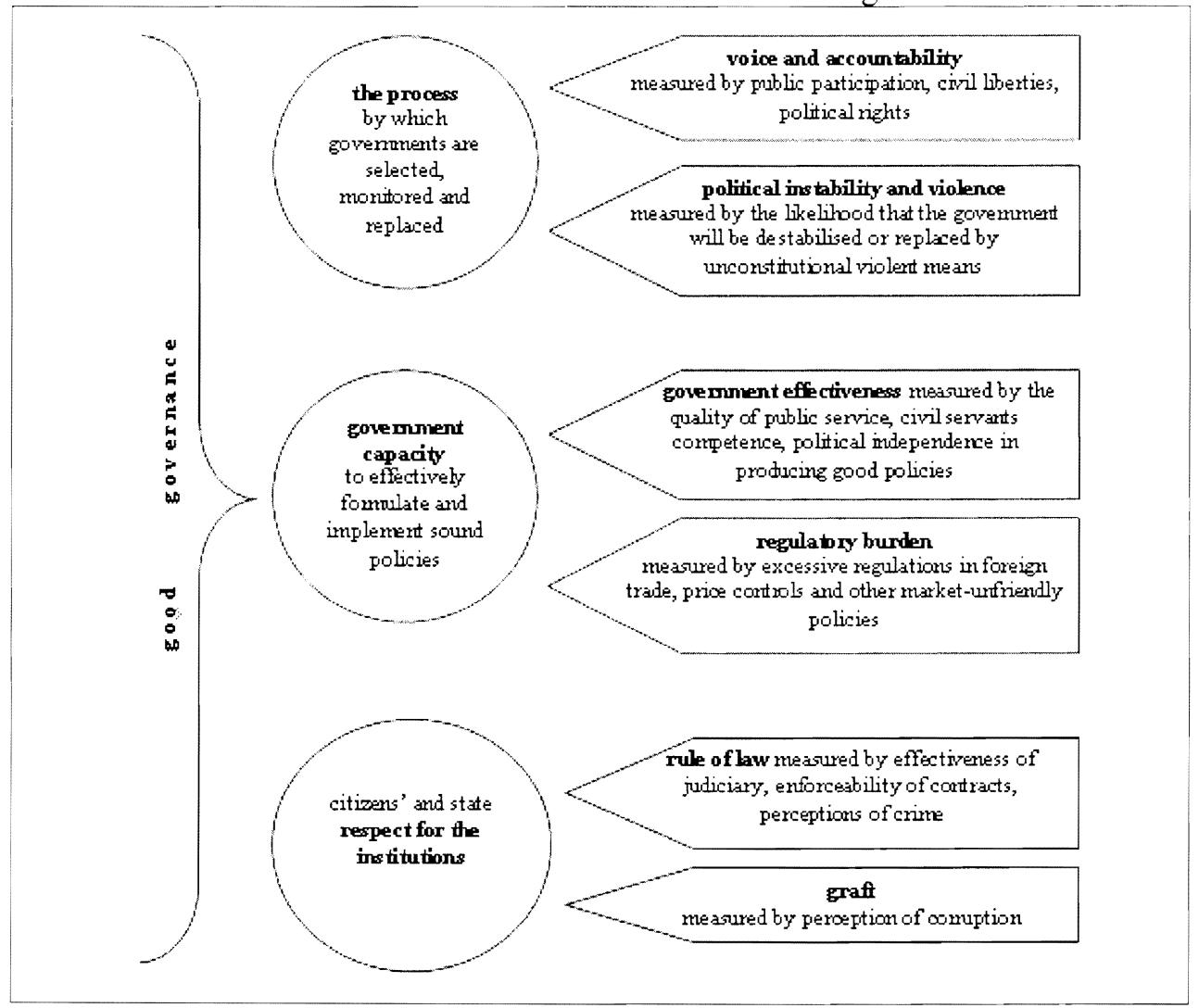

Among various concepts of governance ${ }^{5}$, the closest to the common understanding of governance is a definition of international organisations working on 
improving governance quality in developing countries. For UNDP (2001), governance is understood as the process through which societies take and implement decisions on democratic principles, managing efficiently the allocation of public resources in order to effectively address societal needs.

For countries in transition, such as Croatia, it is important to notice that the quality of governance makes difference ${ }^{6}$. Achieving high quality governance should focus on matching services with citizens' preferences and moving government closer to citizens. Government should ensure political transparency and voice for all, provide efficient and effective public service, promote health and well-being, and create a favorable climate for economic growth (Huther and Shah, 1998).

Although there is no quantifiable definition of good governance, the various dimensions of good governance have been revealed, such as participation, rule of law, transparency, responsiveness, consensus oriented decision-making, equity and inclusiveness, effectiveness and efficiency, accountability, political stability, control

of corruption ${ }^{7}$ (Scheme 1). Attempts to measure various dimensions of governance resulted in constructing different governance databases. They consist of aggregate indicators that strongly reflect perceptions and therefore present better developments in governance quality then comparative ranks ${ }^{8}$.

\section{Good Governance in Croatia}

An overview of good governance assessments of Croatia is given by comparative analysis of six dimensions of governance measured by aggregate indicators (Kaufmann et al., 2003). We have compared assessments of Croatia to selected Central and Eastern European (CEE) countries in transition: Bulgaria, Croatia, Czech Republic, Hungary, Poland, Romania, Slovak Republic and Slovenia (Table 1). Countries were selected by taking into consideration not only the regional affiliation, but also their common efforts to undertake institutional reforms to access the European Union.

In a period from 1996 to 2002 , Croatia made the most noticeable progress in improving responsiveness of the government, free and fair elections, civil liberties and transparency. However, considering voice and accountability among selected CEE countries, in 2002 only Romania lagged behind Croatia. Considering political stability, Croatia stands with Bulgaria and Romania, again ranked far below the best-selected CEE country, Slovenia. Government effectiveness is rather low in all CEE countries, and no significant improvements have been reached in a period 1996 to 2002. Such developments indicate institutional failures regarding bureaucratic quality, institution malfunctioning, government commitment and the quality of public services. The highest total change in government effectiveness for Croatia is 
Table 1.: Good Governance Indicators* for Selected CEE Countries

\begin{tabular}{|c|c|c|c|c|c|c|c|c|c|c|c|c|c|c|c|}
\hline \multirow[t]{2}{*}{$\begin{array}{l}\text { Country } \\
\text { Governance } \\
\text { indicator }\end{array}$} & 1996 & 1998 & 2000 & 2002 & $\begin{array}{l}\text { Total change } \\
\text { 1996-2002** }\end{array}$ & 1996 & 1998 & 2000 & 2002 & $\begin{array}{c}\text { Total } \\
\text { change } \\
1996-2002\end{array}$ & 1996 & 1998 & 2000 & 2002 & $\begin{array}{c}\text { Total } \\
\text { change } \\
1996- \\
2002\end{array}$ \\
\hline & \multicolumn{5}{|c|}{ Voice and Accountability (VOICE) } & \multicolumn{5}{|c|}{ Political Stability (POLSTAB) } & \multicolumn{5}{|c|}{ Government Effectiveness (GOVEFF) } \\
\hline Bulgaria & 0.16 & 0.40 & 0.51 & 0.56 & 0.40 & 0.20 & 0.39 & 0.30 & 0.56 & 0.36 & -0.44 & -0.97 & -0.13 & -0.06 & 0.38 \\
\hline Croatia & -0.47 & -0.30 & 0.38 & 0.46 & 0.93 & 0.38 & 0.61 & 0.37 & 0.56 & 0.18 & -0.22 & 0.29 & 0.16 & 0.19 & 0.41 \\
\hline Czech Republic & 1.01 & 1.14 & 0.99 & 0.90 & -0.11 & 0.95 & 0.95 & 0.85 & 1.02 & 0.07 & 0.60 & 0.72 & 0.71 & 0.70 & 0.10 \\
\hline Hungary & 1.01 & 1.15 & 1.14 & 1.17 & 0.16 & 0.67 & 1.27 & 0.80 & 1.08 & 0.41 & 0.45 & 0.78 & 0.83 & 0.78 & 0.33 \\
\hline Poland & 0.95 & 1.01 & 1.12 & 1.11 & 0.16 & 0.53 & 0.85 & 0.83 & 0.71 & 0.18 & 0.47 & 0.86 & 0.39 & 0.61 & 0.14 \\
\hline Romania & 0.03 & 0.24 & 0.43 & 0.38 & 0.35 & 0.54 & 0.20 & 0.01 & 0.42 & -0.12 & -0.53 & -0.63 & -0.58 & -0.33 & 0.20 \\
\hline Slovak Republic & 0.36 & 0.45 & 0.90 & 0.92 & 0.56 & 0.44 & 0.87 & 0.69 & 1.01 & 0.57 & 0.18 & 0.07 & 0.28 & 0.40 & 0.22 \\
\hline Slovenia & 0.95 & 0.92 & 0.98 & 1.10 & 0.15 & 0.96 & 1.07 & 1.01 & 1.21 & 0.25 & 0.43 & 0.64 & 0.83 & 0.82 & 0.39 \\
\hline \multirow[t]{2}{*}{ CEE average } & 0.50 & 0.63 & 0.81 & 0.83 & 0.33 & 0.58 & 0.78 & 0.61 & 0.82 & 0.27 & 0.12 & 0.22 & 0.31 & 0.39 & 0.27 \\
\hline & \multicolumn{5}{|c|}{ Regulatory Quality (REG) } & \multicolumn{5}{|c|}{ Rule of Law (LAW) } & \multicolumn{5}{|c|}{ Control of Corruption (COR) } \\
\hline Bulgaria & -0.12 & 0.47 & 0.21 & 0.62 & 0.74 & -0.09 & -0.22 & -0.11 & 0.05 & 0.14 & -0.62 & -0.50 & -0.15 & -0.17 & 0.45 \\
\hline Croatia & -0.12 & 0.34 & 0.30 & 0.19 & 0.31 & -0.50 & -0.04 & 0.15 & 0.11 & 0.61 & -0.45 & -0.33 & 0.02 & 0.23 & 0.68 \\
\hline Czech Republic & 0.98 & 0.78 & 0.66 & 1.12 & 0.14 & 0.61 & 0.62 & 0.60 & 0.74 & 0.13 & 0.55 & 0.35 & 0.38 & 0.38 & -0.17 \\
\hline Hungary & 0.47 & 1.15 & 1.09 & 1.21 & 0.74 & 0.62 & 0.78 & 0.85 & 0.90 & 0.28 & 0.59 & 0.69 & 0.76 & 0.60 & 0.01 \\
\hline Poland & 0.34 & 0.83 & 0.60 & 0.67 & 0.33 & 0.44 & 0.57 & 0.64 & 0.65 & 0.21 & 0.38 & 0.49 & 0.47 & 0.39 & 0.01 \\
\hline Romania & -0.43 & 0.30 & -0.27 & 0.04 & 0.47 & -0.27 & -0.25 & -0.21 & -0.12 & 0.15 & $-0 . \overline{17}$ & -0.38 & -0.48 & -0.34 & -0.17 \\
\hline Slovak Republic & 0.18 & 0.29 & 0.36 & 0.76 & 0.58 & 0.11 & 0.13 & 0.32 & 0.40 & 0.29 & 0.39 & -0.08 & 0.25 & 0.28 & -0.11 \\
\hline Slovenia & 0.38 & 0.74 & 0.64 & 0.81 & 0.43 & 0.49 & 0.91 & 0.89 & 1.09 & 0.60 & 0.98 & 0.83 & 1.08 & 0.89 & -0.09 \\
\hline CEE average & 0.21 & 0.61 & 0.45 & 0.68 & 0.47 & 0.18 & 0.31 & 0.39 & 0.48 & 0.30 & 0.21 & 0.13 & 0.29 & 0.28 & 0.08 \\
\hline
\end{tabular}

*Indicators range from -2.5 to 2.5 , with higher values indicating better governance quality.

** Total change represents the difference in the value of indicator in year 1996 and 2002.

Source: Kaufmann et al. (2003): Governance Matters III: Governance Indicators for 1996-2002, Draft for comment, World Bank. 
due to the public administration reforms starting to take place in late 90 -ties. Still regulatory quality in Croatia is the second poorest after Romania, showing restricted new market entries and excessive regulations imposed on business. Rule of law is evaluated very low for all selected countries. In Croatia we consider the low rank is not due to the crime rate, but the result of poor efficiency of judiciary and poor enforceability of contracts. Although all selected countries have bad control of corruption, the control of corruption improved significantly in Croatia from 1996 to nowadays. This measure reflects perception on existing corruption among public officials; frequency of corruption cases reported mentality on corruption and estimated increased impediment to do business due to the irregular payments required.

Our brief comments on good governance indicator values are based on our best knowledge of the situation in Croatia. The strong influence of perceptions reflecting people or experts' view of particular issue may impact the ranking. An illustrative case is the 2 nd world press freedom ranking 9 that is a component of voice and accountability indicator for Croatia. In 2003 Croatia was ranked at the 69th position which is far below the $33 \mathrm{rd}$ position in year 2002. Croatian journalists claimed the survey for Croatia used 'missed criteria', yet the press freedom was improved, particularly due to the new legislation implemented in Croatia in 2002.

Table 2.: Good Governance Index*

\begin{tabular}{|c|c|c|c|c|}
\hline Country & 1996 & 1998 & 2000 & 2002 \\
\hline Slovenia & 0.70 & 0.84 & 0.91 & 0.99 \\
\hline Hungary & 0.64 & 0.96 & 0.91 & 0.96 \\
Czech Republic & 0.78 & 0.74 & 0.70 & 0.81 \\
\hline Poland & 0.52 & 0.73 & 0.68 & 0.69 \\
\hline Slovak Republic & 0.28 & 0.30 & 0.47 & 0.63 \\
\hline CEE average & 0.30 & 0.42 & 0.48 & 0.58 \\
\hline Croatia & -0.23 & 0.09 & 0.23 & 0.29 \\
\hline Bulgaria & -0.15 & -0.12 & 0.11 & 0.26 \\
\hline Romania & -0.14 & -0.18 & -0.18 & 0.01 \\
\hline
\end{tabular}

*Values range from -2.5 to 2.5 , with higher values indicating better overall governance quality. Good Governance Index (GGI) is an aggregate measure of six dimensions of good governance, calculated as an average of six indicators of governance. Countries are ranked according to the value of GGI in 2002.

Sources for original data: Kaufmann et al. (2003): Governance Matters III: Governance Indicators for 1996-2002, Draft for comment, World Bank

We have constructed a good governance index (GGI) as a simple aggregate measure of overall good governance country' position and developments. Good 
governance index (GGI) is calculated as an average value of six indicators: voice and accountability (VOICE), political stability (POLSTAB), government effectiveness (GOVEFF), regulatory quality (REG), rule of law (LAW), control of corruption $(\mathrm{COR})^{10}$. Although the governance quality is improving, GGI in year 2002 still ranks Croatia on the bottom of the comparative countries ranking (Table 2).

The aggregate good governance index may be used to test the general hypothesis that good governance is a key determinant of the ability to pursue sustainable economic and social development (UNDP). The examined correlation between Good Governance Index (GGI) and Human Development Index (HDI) ${ }^{11}$ in year 2000 confirms there is a strong positive correlation between good governance assessment and high level of human development achieved. We applied Spearman rank order correlation analysis to the selected group of eight CEE countries (Table 3). Spearman rank correlation coefficient is 0,87 what is above the theoretical value $(0,643)$. The results for year 2000 showed for selected countries that higher value of GGI is associated with higher value of HDI. Slovenia and Hungary are the best ranked, while Bulgaria and Romania are the lowest ranked CEE countries (Figure 1).

Table 3.: Results of Spearman Rank Order Correlation

\begin{tabular}{|l|c|c|c|c|}
\hline & Valid $N$ & Spearman $\mathrm{t}$ & $\mathrm{t}(\mathrm{N}-2)$ & $\mathrm{p}$-level \\
\hline GGl00 and HDI00 & 8 & 0.873494 & 4.394948 & 0.004593 \\
\hline
\end{tabular}

GGI00-Good Governance Index 2000, HDI00-Human Development Index 2000

Source: Authors' calculation.

The results of such an analysis are to be used to create incentive institutional framework and to formulate policy that will improve the quality of governance (or one particular governance dimension), so trends and cross-country analysis of aggregate indicators is not sufficient. Due to the high level of abstraction and overlapping input factors, we would first test if there is a correlation among indicators of governance dimensions and basic development indicators: education index (EDU), life expectancy index (LIFE) and gross domestic product index (GDP) ${ }^{12}$. The analysis of nine indices including six dimensions of good governance and three components of HDI has been made for eight CEE countries in year 2000 (Table 4).

A strong positive correlation is observed between GDP Index (GDP) and Government Effectiveness (GOVEFF). The high correlation is also observed among different good government indicators. The highest positive correlation exists among the following pairs of variables: Government Effectiveness (GOVEFF) and Regulatory Quality (REG), Government Effectiveness (GOVEFF) and Rule of Law (LAW), Government Effectiveness (GOVEFF) and Control of Corruption (COR), Regulatory Quality (REG) and Rule of Law (LAW), and Rule of Law (LAW) and Control of Corruption (COR). The findings confirm our hypothesis that for the 
selected countries, government effectiveness, regulatory quality and rule of law have positive correlation to control of corruption.

Figure 1.: Good Governance and Human Development, year 2000

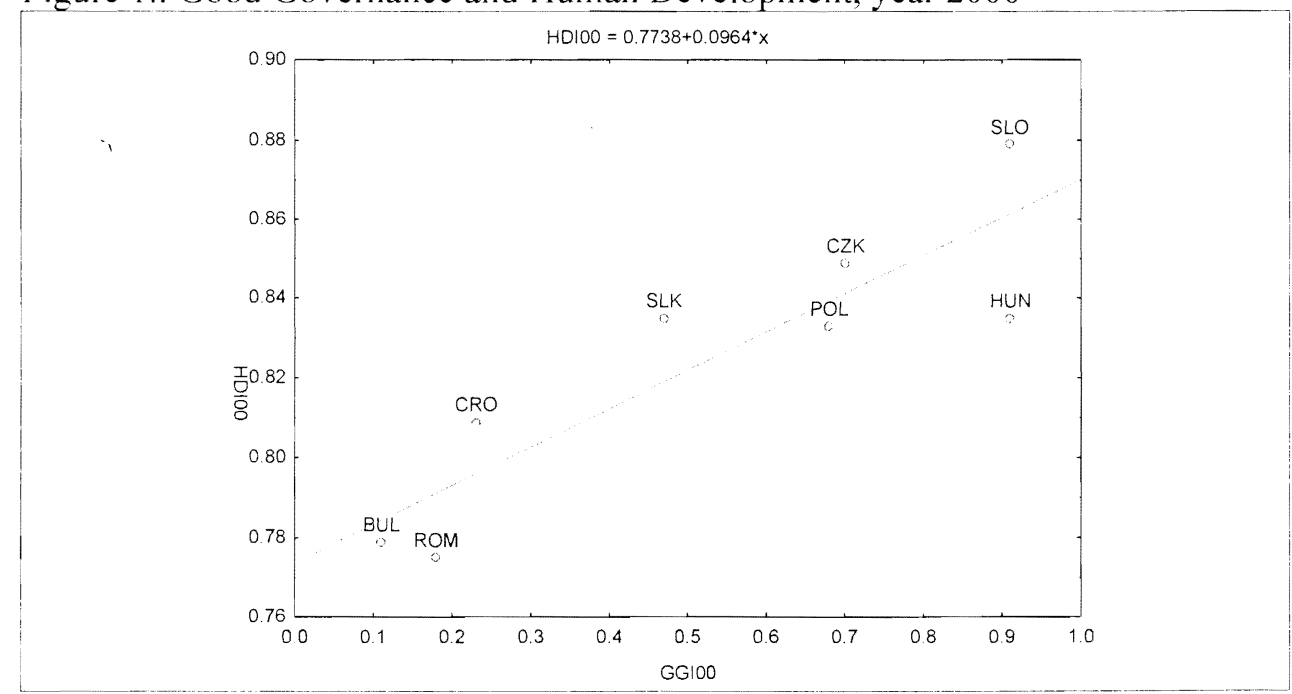

Explanatory Notes: HDI00-Human Development Index 2000, GGI00-Good Governance Index 2000; BUL-Bulgaria, CRO-Croatia, CZK-Czech Republic, HUN-Hungary, POL-Poland, ROM-Romania, SLK-Slovakia, SLO-Slovenia

Sources: For GGI original data: Kaufmann et al. (2003); for HDI: UNDP (2003): Human Development Report

Table 4.: Correlation Matrix of HDI Components and Good Governance Indicators, 2000

\begin{tabular}{|c|ccc|c|c|c|c|c|c|}
\hline Variables & EDU & I..JFE & GDP & VOICE & $\begin{array}{c}\text { POLST } \\
\text { AB }\end{array}$ & $\begin{array}{c}\text { GOVEF } \\
\text { F }\end{array}$ & REG & LAW & COR \\
\hline EDU & 1 & 0,32 & 0,55 & 0,80 & $-0,13$ & 0,64 & 0,67 & 0,77 & 0,82 \\
LIFE & 0,32 & 1 & 0,76 & 0,44 & $-0,44$ & 0,69 & 0,44 & 0,65 & 0,66 \\
\hline GDP & 0,55 & 0,76 & 1 & 0,75 & $-0,53$ & 0.90 & 0,72 & 0.89 & 0,89 \\
\hline VOICE & 0,08 & 0,44 & 0,75 & 1 & $-0,37$ & 0,81 & 0,83 & 0,89 & 0,82 \\
\hline POLSTAB & $-0,13$ & $-0,44$ & $-0,53$ & $-0,37$ & 1 & $-0,35$ & $-0,23$ & $-0,47$ & $-0,35$ \\
\hline GOVEFF & 0,64 & 0,69 & 0,90 & 0,81 & $-0,35$ & 1 & 0,94 & 0,96 & 0,94 \\
\hline REG & 0,67 & 0,44 & 0,72 & 0,83 & $-0,23$ & 0,94 & 1 & 0,90 & 0,86 \\
\hline LAW & 0,77 & 0,65 & 0,89 & 0,89 & $-0,47$ & 0,96 & 0,90 & 1 & 0,97 \\
\hline COR & 0,82 & 0,66 & 0,89 & 0,82 & $-0,35$ & 0,94 & 0,86 & 0,97 & 1 \\
\hline
\end{tabular}

Source: Authors ' calculation. Source of original data: UNDP Human Development Report (2002), Kaufmann et al. (2003) 
The results of the analysis of good governancet indicators for Croatia in years 1996, 1998, 2000, 2002 show slightly different connection (Table 5). The highest correlation exists between Voice and Accountability (VOICE) and Control of Corruption (COR), as well as between Government Effectiveness (GOVEFF) and Regulatory Quality (REG).

Table 5.: Correlation Matrix of Good Governance Indicators for Croatia

\begin{tabular}{|c|ccc|c|c|c|c|}
\hline Variables & VOICE & POLSTAB & GOVEFF & REG & LAW & COR \\
\hline VOICE & 1 & 0.02 & 0.50 & 0.49 & 0.85 & 0.98 \\
\hline POLSTAB & 0.02 & 1 & 0.69 & 0.50 & 0.34 & 0.16 \\
GOVEFF & 0.50 & 0.69 & 1 & 0.96 & 0.86 & 0.50 \\
\hline REG & 0.49 & 0.50 & 0.96 & 1 & 0.87 & 0.44 \\
\hline LAW & 0.85 & 0.34 & 0.86 & 0.87 & 1 & 0.82 \\
COR & 0.98 & 0.16 & 0.5 & 0.44 & 0.82 & 1 \\
\hline
\end{tabular}

Source: Authors' calculation. Source of original data: Kaufmann et al. (2003)

Once the correlation has been confirmed, further analysis of determinants and effects of particular governance dimension remains to be done. Since the purpose of this work is however, to show the importance of institutional environment in which good governance is assessed, we will proceed with more in-depth analysis of country specifics regarding corruption in Croatia.

\section{Corruption in Croatia}

Corruption is most commonly defined as the abuse of public power for private benefit (Tanzi, 1998). The recent research revealed discretionary power and associated economic rent as well as poor governance quality as main determinants of corruption, and examined its deterrent effects to the economy ${ }^{13}$. Research has shown that investors in CEE see corruption as second most important obstacle (after tax regulations and/or high taxes) for doing business (Brunetti et al., 1997).

The governance indicators measuring the phenomena of corruption available for Croatia are shown in Table 6.

The Transparency International Corruption Perceptions Index (CPI) is a composite index that ranks countries in terms of the degree to which corruption is perceived to exist among public officials and politicians ${ }^{14}$. Among the selected CEE countries, Slovenia and Hungary are perceived as the less corrupted countries, while Romanian public sector is worse off in terms of corruption (Table 7). 
Table 6.: Indicators on Corruption and Sources Available for Croatia

\begin{tabular}{|c|c|}
\hline Indicators & Sources \\
\hline Corruption Perception Index & Transparency International \\
\hline Control of Corruption & Kaufmann et al. \\
Corruption & Political Risk Services \\
\hline Bribe tax & Business Environment and Enterprise Performance \\
& Survey \\
\hline
\end{tabular}

Source: Authors' systematisation.

Data for Croatia are available for the 1999-2002 period and they show the rather high perception of corruption in the Croatian public sector, and the total ranking in the middle of the world list. In 2002 Croatia occupied the 51 st place out of 102 total number of countries surveyed.

Table 7.: Corruption Perceptions Index (CPI)

\begin{tabular}{|c|c|c|c|c|c|c|c|}
\hline Country & 1996 & 1997 & 1998 & 1999 & 2000 & 2001 & 2002 \\
\hline Bulgaria & - & - & 2.9 & 3.3 & 3.5 & 3.9 & 4.0 \\
\hline Croatia & - & - & - & 2.7 & 3.7 & 3.9 & 3.8 \\
\hline Czech Republic & 5.4 & 5.2 & 4.8 & 4.6 & 4.3 & 3.9 & 3.7 \\
\hline Hungary & 4.9 & 5.2 & 5.0 & 5.2 & 5.2 & 5.3 & 4.9 \\
\hline Poland & 5.6 & 5.1 & 4.6 & 4.2 & 4.1 & 4.1 & 4.0 \\
\hline Romania & - & 3.4 & 3.0 & 3.3 & 2.9 & 2.8 & 2.6 \\
\hline Slovakia & - & - & 3.9 & 3.7 & 3.5 & 3.7 & 3.7 \\
\hline Slovenia & - & - & - & 6.0 & 5.5 & 5.2 & 6.0 \\
\hline
\end{tabular}

Source: Transparency International (2003).

The research on corruption and public availability of information conducted by Transparency International Croatia ${ }^{15}$ confirmed the CPI rankings. Almost 86 per cent of respondents considered corruption widespread or extensively widespread in Croatia. Citizens see the corruption as the third most important problem facing the country today, after unemployment and poverty (IDEAS, 2003).

Corruption occurring in the health and judicial sector seems to be the most painful to the Croatian citizens. 22.5 per cent of Croats who have participated in the Transparency International Global Corruption Barometer (GCB) 2003 would first eliminate the corruption in the medical services (Figure 2). The high public sensitivity to corruption in health services is a result of increased direct costs to individuals. Otherwise publicly provided medical services in Croatia are considered 'free and for granted'. However, it does not mean that the perceived existence of corruption in other sectors is low. The good example is police: 57.7 per cent of Croats 
responded in the Transparency International Croatia survey that the corruption in police is widespread, but very few respondents of the GCB would give priority to elimination of corruption in police. ${ }^{16}$ The high level of tolerance expressed in the low 4.2 per cent of anti-corruption priorities given to police sector could be explained with the high level of opportunism (citizens prefer to bribe officers to avoid high fines).

Figure 2.: Priority Sectors to Eliminate Corruption in Croatia

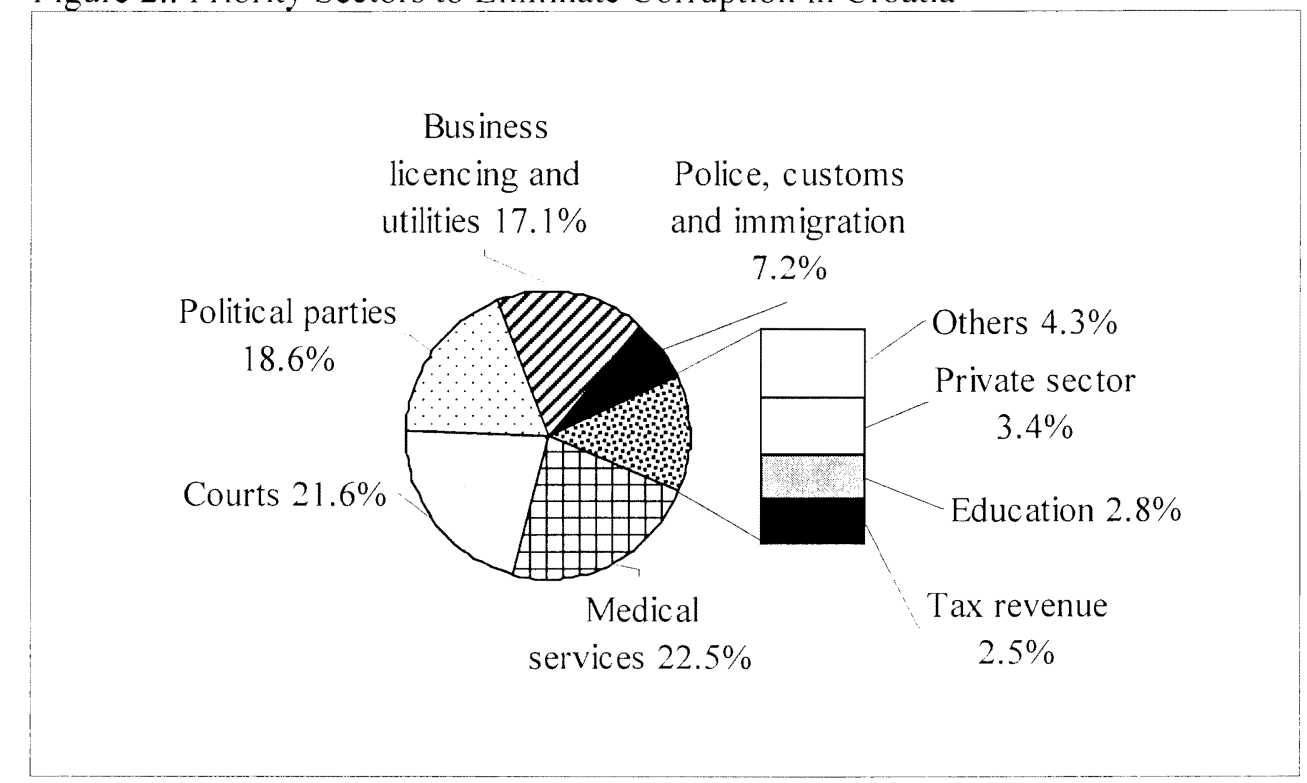

Source of original data: Global Corruption Barometer 2003, Transparency International.

However, the optimistic expectations on anti-corruption efforts in Croatia are promising. The expectations of almost 44 per cent of respondents that the corruption will decrease in the next three years bring Croatia on the top of the list of optimistic countries (GCB 2003). The background for this optimism remains to be tested, where the following assumptions could be considered:

a) the awareness of corruption being a real (and for a long time neglected) problem in Croatia has been raised, and

b) the trust in institutions set in the post-war and post-privatisation period has increased and institutional improvements achieved within the process of Croatia's accession to the EU recognised in public. 
The first assumption is related to the achievement of good governance principles. Although the national anti-corruption program defines eight priority areas to fight corruption $^{17}$, it is clear that additional measures are needed to effectively combat corruption such as reform of judiciary, transparency in public administration activities, decrease of bureaucratic procedures, easy access to information (Kregar, 2003).

The second assumption remains to be tested by survey on trust in institutions in Croatia. However, the fact that formally the National Program for the Fight Against Corruption with an Action Plan has been adopted in 2002 and national institutions established, the activity of Transparency International Croatia has been promoted in media, some cases of corruption have been processed confirm at least normative improvements in the institutional settings that may raise optimism in future seizing of corruption.

Figure 3.: Criminal Offence of Corruption in Croatia, 1998-2002

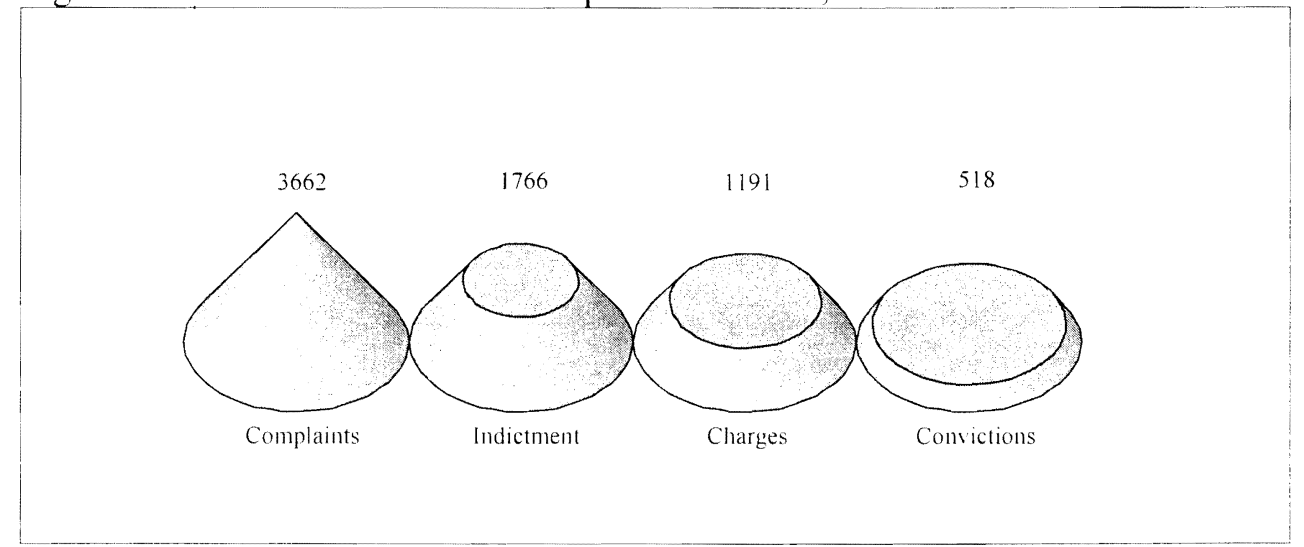

Source of original data: Central Bureau of Statistics of the Republic of Croatia, Adults perpetrators of criminal offence against official duty

Finally, subjective measurement of the perceived existence of corruption is to be compared with the official statistics of corruption cases reported and processed. The share of officially registered cases of corruption in the total corruption is subject to estimates. More indicative is the ratio of reported corruption cases being sanctioned. It depends on enforcement, independence of judiciary and equal access to the law for everyone (Jain, 2001). In the period 1998 to 2002 in Croatia the criminal offence of corruption including giving bribes, taking bribes and offence against official duty represented only 1.4 per cent of total number of adult perpetrators of criminal offence. Out of total of 3662 corruption complaints raised at courts just 14 per cent were sanctioned with convictions (Figure 3). 


\section{Corruption at the Local Level}

Somehow it is always considered that the corruption problem is less exaggerated at the local level or, at least that is less harmful. Both notions are not true. Corruption is hard to be revealed in smaller communities because of the fear of reporting the suspicious cases. Since it has roots in informal institutions it might be even harder to fight corruption locally than nationally.

Table 8.: Regional Perceptions of Corruption in Local Governments in Croatia

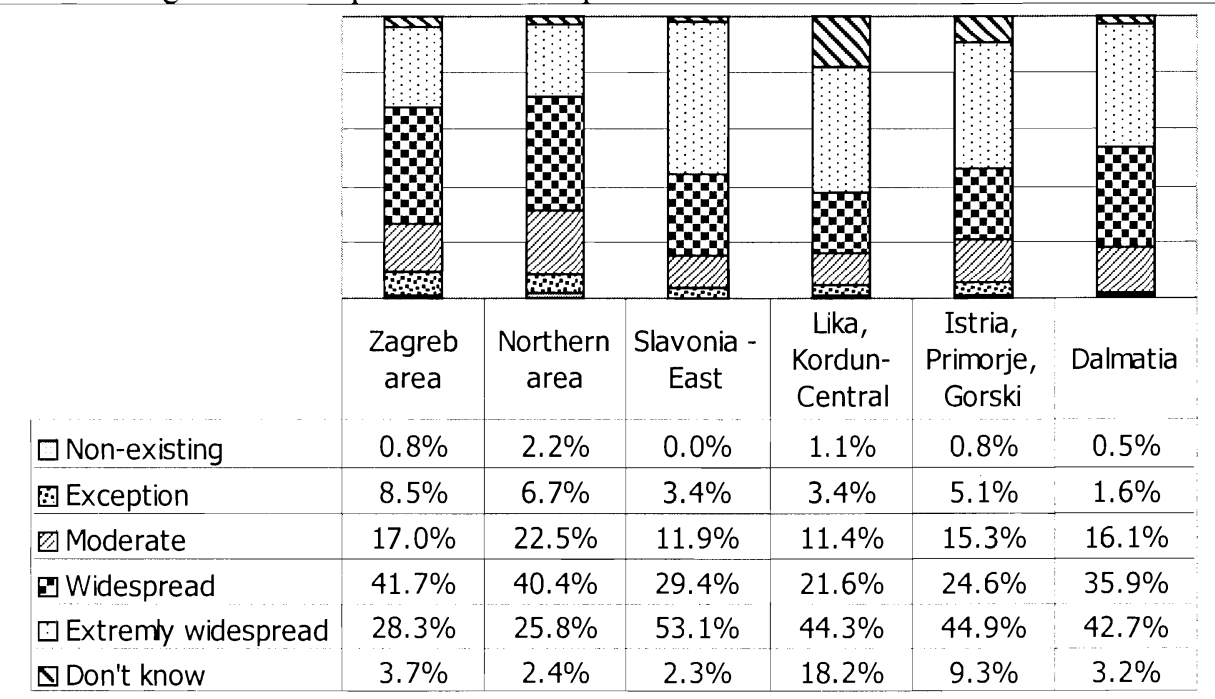

Source: Authors' calculation. Source of original data: Survey of Transparency International Croatia.

The study of perception of corruption of local governments and local officials in Croatia may serve as a direction where to target the local anti-corruption activities since the data are sorted by regions and the size brackets of towns and municipalities ${ }^{19}$. Generally, a high percentage of responders (72.8 per cent) consider the local governments are widely (34.4 per cent) or extremely corrupted (38.4 per cent). The noticed variations among regions are shown in Table 8.

Citizens in the eastern part of Croatia are more convinced that corruption is widespread in the local government than responders living in the north regions and in the capital city of Zagreb area. The further analysis shows that corruption in local government is perceived to be evenly present in small municipalities as well as in bigger towns. 
The total of 10 per cent of respondents considers that local officials are not corrupted at all, and almost 60 per cent consider that local officials are highly corrupted (Figure 4). However, the opinion of respondents in the coastal Dalmatia area indicates the higher perception (67 per cent) of very corrupted local officials. The post-war political developments in Slavonia region may explain the highest perception of corruption (over 73 per cent) among the category of 'county prefects, prefects' deputies and mayors'. 70 per cent of all respondents consider that civil servants working in local administration of mid-size towns ${ }^{20}$ are very corrupted.

Figure 4.: The Perceived Level of Corruption of Local Officials in Croatia*

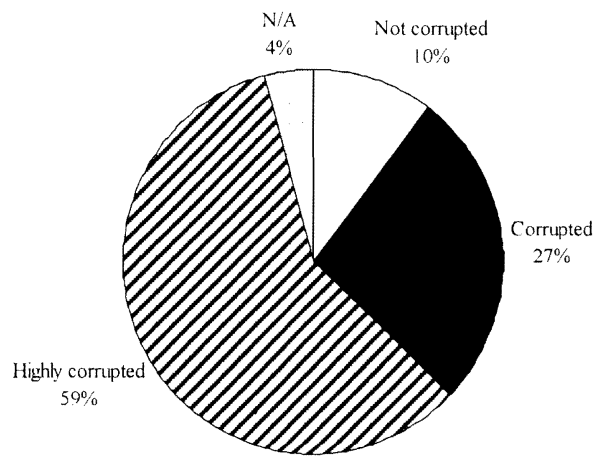

* The exact question was: According to your opinion, how much corrupted are individual public and state officials? The results are summarised for two categories: a) county prefects, deputies, mayors, and b) civil servants in local administrative bodies - county administration offices, city councils, municipality administration services, etc.

Source of original data: Survey of Transparency International Croatia.

Another opinion poll on the areas of governance that need the most urgent improvements was conducted at the local level in Croatia. It showed similar results: 69 per cent of citizens ascribed importance to measures and activities targeted to decrease in corruption. The variance above the Croatian average has been noted in underdeveloped regions that have suffered the war damages the most. In the County of Vukovar-Sirmium, 75 per cent of responders ascribed importance to a decrease in corruption $^{21}$.

National anti-corruption policy defines decentralisation as one of the anti-corruption priorities ${ }^{22}$. The fiscal decentralisation is empirically proved to be strongly and negatively associated to corruption (Fisman and Gatti, 2000). Although decentralisation contributes to lower risk of corruption at the central level, it might 
have contrary effects at the local level. Decentralisation process increases the risk of local corruption by transferring more power to the local government. On the other hand, the increasing number of small-sized local government units in Croatia seized their financial, human and organisational capacities and reduced their autonomy in performing decentralised functions (Budak, 2003). Decentralisation in contrary, reinforced centralist tendencies while interest groups lobbying and local individuals in power influence weak local authorities. If other institutional settings do not provide transparent processes and functioning of control mechanism, the possibility of corrupted activities is increased. Conclusively, establishing proper institutional framework and effective institutions is a key factor to fight corruption, both at national and local level.

\section{Conclusion}

The objective of this research was to examine the good governance assessments and their dependence to the institutional development. The analysis of good governance indicators in a period from 1996 to 2002 showed that quality of good governance has slightly improved in all selected CEE countries. However, Croatia remains on the bottom of the comparative countries ranking regarding all dimensions of good governance within the whole period. A good governance index we have constructed to measure overall a good governance assessment of a particular country confirms the low ranking for Croatia in the latest year 2002.

Based on analysis it could be concluded that dimensions of good governance for Croatia and selected CEE countries highly correlate. The correlation has also been observed among basic development indicators and good governance indicators. Further research should examine the interdependencies among good governance and development indicators in order to set determinants and effects of good governance dimensions to development outcomes. Since aggregate indicators are mostly results of perceptions, the analysis should consider institutional development as well.

The analysis of corruption perception followed by institutional explanations of corruption at the national and local level in Croatia, confirmed the thesis that country-specific model has to be built for particular analysis. The model should contain institutional environment within which the good governance assessments are to be explained. Such a research model would provide results according to which policy measures to improve governance quality could be advised. 


\section{NOTES}

' See more in Ahrens, J. (2002).

2 Process indicators such as civil service employment and pay, index of meritocratic hiring. internal promotion and bureaucratic career stability, political regime characteristics and political constraint index are examples of institutional quality indicators describing mostly political determinants of growth and development.

${ }^{3}$ Formal constraints are political and economic rules, contracts, while informal constraints are part of the heritage we call culture such as norms of behavior and common law.

${ }^{4}$ Based on Kaufmann et al. (1999).

5 See more in Campos (1999).

${ }^{6}$ Regarding good governance dimensions and indicators, this paper partly refers to Badjun, M. (2003). Good governance indicators and impact on economic growth and development - national level. working paper, Good Governance in Croatia Terms of References for UNDP, Zagreb, Croatia. Authors gratefully acknowledge contributions of Marijana Badjun.

${ }^{7}$ See United Nations Economic and Social Commission for Asia and Pacific, wiww unescap.org: Kaufmann et al. (1999, 2002, 2003), World Bank $(1992,2002)$

${ }^{8}$ More on methodology of aggregating governance indicators, see in Kaufmann, D.; Kraay, A.; Mastruzzi, M. (2003): Governance Matters III: Governance Indicators for 1996-2002, Draft for comment, World Bank.

${ }^{9}$ Reporters sans frontierès hitp:/ w ww.rsforg/article.php3?id article $=8247$, Slobodna Dalmacija, hep:/4mw slobodnadalmacija.hr/20031022/novostios.asp

${ }^{10}$ Some authors use good governance indicators as «institutional factors» and related aggregate index refer as «institutional development index». For example, see: Nunnenkamp, P. (2003).

"Human Development Index is an aggregate measure of economic and social development indicators, such as life expectancy at birth, literacy rate, school enrollment ratio, GDP p.c. For HDI methodology, see: UNDP (2003): Human Development Index Technical Note.

${ }^{12}$ Education index is based on the adult literacy rate and the combined primary, tertiary and tertiary enrollment ratio. Life expectancy index measures relative achievements of a country in life expectancy at birth. GDP index is based on GDP per capita (PPP US). Human Development Index (HDI) is a simple average of education index, life expectancy index and GDP index. For HDI methodology, see: UNDP (2003): Human Development Index Technical Note. .

${ }^{13}$ There is an extensive research work on definition, determinants and effects of corruption. For review, see Jain (2001) and Tanzi (1998).

${ }^{14}$ The CPI focuses on corruption in the public sector and defines corruption as the abuse of public office for private gain. It is based on surveys carried out among business people and country analysts and ranges between 10 (highly clean) and 0 (highly corrupt). Data are available from Transparency International (2003).

${ }^{15}$ Survey was conducted on 1000 citizens. Transparency International Hrvatska (May 2003). 
${ }^{16}$ Global Corruption Barometer, Transparency lnternational (2003).

${ }^{17}$ The rule of law and effectiveness of judiciary, establishment of an administrative body to effectively combat corruption, increased efficiency of criminal justice, set of organisational measures in the public administration system, decentralisation, measures of financial responsibility and other economic measures, internationals activities, encouraging political and citizens' responsibility.

${ }^{19}$ Survey was conducted on 1000 citizens. Transparency International Hrvatska (May 2003).

${ }^{20}$ Population of 10.000 to 100,000 .

${ }^{21}$ The opinion poll was conducted by Croatian Law Center through the PULS agency in June 2002, for internal purposes, so the results are not officially available to the public.

${ }^{22}$ National Action Plan for the Fight against Corruption, Official Gazette No. 34/02

\section{REFERENCES}

Ahrens, J. (2002), Governance and economic development: a comparative institutional approach. Cheltenham, UK ; Northampton, MA, USA: E. Elgar.

Badjun, M. (2003). Good governance indicators and impact on economic growth and development national level, working paper, Good Governance in Croatia Terms of References for UNDP. Zagreb, Croatia.

Campos, N. F. (1999), 'Development Performance and the Institutions of Governance: Evidence from East Asia and Latin America', World Development, Vol. 27 (1999), no. 3, pp. 439-452.

Huther, J.; Shah. A. (1998), Applying a Simple Measure of Good Governance to the Debate on Fiscal Decentralization, Working Paper, No. 1894, World Bank.

IDEAS (2003), South Eastern Europe: New Means for Regional Analysis, [online]. Institute for Democracy and Electoral Assistance, available from: http://www.idea.int/balkans/results /Croatia/cro_gen2.htm [13.06.2003.]

Jain, A. (2001), 'Corruption: A Review', Journal of Economic Surveys, Vol. 15, no. 1, pp.71-121.

Jeffries. I. (2001), Good Governance and the First Decade of Transition : An Overview. in Hoen (Ed.), Good Governance in Central and Eastern Europe. Cheltenham, UK: Edward Elgar, 2001.

Kasper, W.; Streit, M.E. (1998), Institutional economics. Cheltenham, UK: Edward Elgar, 1998.

Kaufman, D.; Kraay, A. (2002), Growth without Governance, Working Paper, No. 2928, World Bank.

Kaufmann, D.; Kraay, A.; Zoido-Lobaton, P. (1999), Governance Matters, Policy Research Woking Paper, No. 2196, World Bank.

Kaufmann, D.; Kraay, A.; Zoido-Lobaton, P. (2000), Governance Matters: From Measurement to Action [online], Finance and Development, Vol. 37, no. 2, available from: http://www.imf.org/external/pubs/ft/fandd/2000/06/kauf.htm, [05.06.2003.].

Kaufmann, D.; Kraay, A.; Zoido-Lobaton, P. (2002), Governance Matters II: Updated Indicators for 2000/01, Working Paper, No. 2772, World Bank.

Kaufmann, D.; Kraay, A.; Mastruzzi, M. (2003), Governance Matters III: Governance Indicators for 1996-2002, Draft for comment, World Bank.

Kregar, J. (2003), Corruption in Croatia: Risks and Actions [online], available from: http://www.transparency.hr/ [18.09.2003]

North, D. (1990), Institutions, institutional change and economic performance. Cambridge, UK: Cambridge University Press. 
Reporters sans frontièrs (2003), World Press Freedom Ranking [online], available from: http://www.rsf.org/article.php3?id_article=8247 [04.11.2003]

Tanzi, V. (1998), Corruption Around the World, IMF Staff Papers, Vol. 45, no. 4

Transparency International (2003), Corruption Perceptions Index [online], available from: http://www.transparency.org/cpi/index.html\#cpi, [13.06.2003]

Transparency International (2003), Global Corruption Barometer [online], available from: http://www.globalcorruptionreport.org/ [19.09.2003]

Transparency International Hrvatska (2003), Korupcija i javnost informacija; stavovi i iskustva [online], available from: http://www.transparency.hr/stari/istrazivanja/korupcija_tablice.pdf [19.09.2003]

UNDP (2001), Rebuilding state structures: methods and approaches, United Nations Development Programme, New York.

UNDP (2003), Human Development Report, United Nations Development Programme available from: http://www.undp.org/hdr2003/indicator/ [25.09.2003]

UNDP (2003): Human Development Index Technical Note, United Nations Development Programme available from: http://www.undp.org/hdr2003/pdf/hdr03 backmatter_2.pdf, [06.11.2003]

UN ESCAP (2003), What is Good Governance?. [online]. United Nations Economic and Social Commission for Asia and the Pacific, available from: http:/www.unescap.org/ huset/gg/governance.htm, [05.06.2003.]

Van de Mortel, E. (2002), An Institutional Approach to Transition Processes, Hampshire, UK, Ashgate.

World Bank (1992), Governance and Development, Washington, D.C.

World Bank (2002), World Development Indicators Database. 